Folomieieva Natalya

$\mathrm{PhD}$ in Pedagogy, Department of choral conducting, vocal and methodic of musical education, docent, Sumy state pedagogical University named after A.S. Makarenko Sumy, Ukraine

folomeeva.natalya.arkadievna@gmail.com

ORCID ID 0000-0002-7832-4748

\title{
METHOD OF USE OF TECHNICAL TOOLS AND SOFTWARE IN THE PROCESSES OF PROFESSIONAL TRAINING OF FUTURE ARTIST - VOCALIST
}

\begin{abstract}
The article is devoted to the basics of the methodology of the use of technical tools and software in the process of professional training of future bachelors of musical art - artists-vocalists in artistic institutions of higher education. The main terms of use of technical means and software are offered in the course of professional training of future bachelors of music art - artists-singers in higher education institutions. Also, the article defines the terms of use of software in the process of mastering the future artists-singers of the course «Pop singing» in the process of training in the specialty «Music Art». The research outlines the main methodological recommendations for using the features of the direction of the microphone and the equalizer of the mixing console for individual classes on pop singing in the process of professional training of future pop singers. The emphasis is placed on the importance of using in the process of professional training for future bachelors of musical art software for recording rehearsal work. The conclusion is made on the necessity and importance of further improvement of curricula and educational and professional programs of the specialty «Musical art» in order to deepen the practical and technical component of the process of professional training, in particular, in the specialty «Pop Singing».
\end{abstract}

Key words: pop music; musical arts; bachelor of musical arts; technical tools; software; Adobe Audition; microphone; mixing console.

Substantiation of the relevance of the problem. The development of technologies is inextricably linked with the development of modern society, and, accordingly, technology has affected many spheres of social life, among which education play an important role. In the process of obtaining a qualification in modern institutions of higher education, the acquisition of technical tools and computer programs by students is of indisputable importance for ensuring the quality of professional training and readiness for professional activity in the modern technological and informational world. Therefore, the process of professional training can not be considered successful without mastering in higher education institutions a method of using technical tools and software. The general tendency of development of modern education and professional training is to shift the emphasis from mass educational phenomena to individual, since the individual approach allows maximally fulfilling the educational tasks. Unlike other areas of higher education, in the artistic higher education individualization of the process of professional training is a traditional feature. However, at the present stage of the development of artistic education, the importance of using technical tools and computer programs, along with legislative and theoretical substantiation, does not have sufficient level of methodological support. Accordingly, methodological substantiation of the methodology of the use of technical tools and software in the process of professional training of future bachelors of musical art - artists-vocalists in modern educational institutions of higher education becomes especially relevant.

Analysis of scientific research. The various components of the future singer vocal training process are thoroughly studied in scholarly works: S. Austin (Austin, 2008), R. Lebon (Lebon, 1999), J. LoVetri (LoVetri, 2003), and others. The mastery of vocal techniques is explored in works: R. Edwin (Edwin, 1996), R. Miller (Miller, 2000), A. Peckham (Peckham, 2006), S. Riggs and J. Carrtello (Riggs, Carrtello, 1998) and others. A large number of scientific, methodological and practical works are devoted to the study of the use of technical tools and computer programs: K. Bozeman (Bozeman, 2007), R. Lebon (Lebon, 1999) and others, attention is paid to the protection of voice: C. Heinze (Heinze, 
1997, p. 31) and others. However, in the studied scientific works, the methodology of using specific tehnical tools and a computer program in the process of professional training of future artists - vocalists is insufficiently covered, therefore this problem remains relevant.

The purpose of the article. Accordingly, the purpose of the study is to determine the methodological basis for the use of technical tools and software in the process of training future bachelors of music art - artists-vocalists. The objectives of the study determined the specification of the method of using technical tools to ensure the acquisition of a specialty in individual occupations in the specialty; the application of computer programs in the process of mastering specialization, as well as the specification of conditions for the use of technical tools and software in the process of training future bachelors of music art - singers-vocalists.

Presenting main material. In the conditions of modern professional activity of the artists - vocalist and, especially, the pop singer, the use of technical tools is justified by the production necessity. Accordingly, in order to ensure the necessary level of competitiveness of a graduate of an arts institution of higher education, it is connected with mastering the method of using technical tools in the process of professional training. Effectiveness and productivity of the learning process, the effectiveness of using different methods and forms of learning in it is directly related to the choice of teaching aids. Necessary factors contributing to the successful acquisition of knowledge are technical tools of training. In the conditions of rapid growth of information flows and an increase in the shortage of classroom teaching time, technical tools allow exposing and absorbing a much larger amount of educational knowledge in a limited time. At the same time, the quality of information absorbed by students increases due to the activation of various perceptual components of the perception process. The use of various technical tools in the process of professional training increases the efficiency of the educational process, enhances the absorption of the educational material, and their development and definition of the directions of application is an important part of the methodical work of the higher educational institutions of arts. Therefore, in the discourse of reforming the educational sector, it is important to deepen the methodological substantiation of the use of technical tools and software, in particular, future bachelors of music artists singers-vocalists.

The basic discipline of the cycle of professional training in the specialty 025 «Music Art», the mastery of which ensures the mastery of professional competence, is a specialty. For specialization «Pop singing» is the «Pop singing» training course, which day-time students of the Educational-Scientific Institute of Culture and Arts study in accordance with the approved curricula and educational and professional programs throughout the entire period of study. The subject of mastering the discipline «Pop singing» is the content of the practical training of students for activities as an artist - vocalist, arming with their basic knowledge about the structure of the vocal apparatus and the peculiarities of its functioning, the formation of the necessary vocal and performing skills, skills and professional competence of future bachelors of musical art. The process of training is carried out in the form of individual classes, in which the training on the specialty of each student is carried out separately. This form involves setting up each student - the future pop artist - vocalist specially selected, in accordance with the level of his training and vocal opportunities, a task whose solution is based on the close interaction of the student and the teacher in the specialty. Accordingly, on individual lessons, for each student separately, according to his musical-performing possibilities, there are varied vocal pieces that make up the educational repertoire; they learn their skills, mastery of vocal techniques and techniques necessary for their implementation, etc. For pop singers, the important component is the use of various technical tools in the process of performance variety vocal works. The program of the «Pop Singing» course envisages mastering the methodology of the use of technical tools in the process of training of pop vocal concert performances. The technical tools used in individual classes in the «Pop 
Singing» course include: microphone, preamplifier, sound processing devices, mixing console, etc. Taking into account the high level of informatization on individual lessons, software such as digital audio workstations such as Adobe Audition (Adobe Audition CC, 2017) is also used.

Before considering the methodical principles of the use of technical tools and software, it is expedient, based on the analysis of theoretical and methodological details in the implementation of this aspect, as well as practical experience, to determine the main conditions of use of technical tools and software in the process of training future bachelors of music art - singers-vocalists.

A. Sufficient level of technological process of professional training of future bachelors of musical art - artists-vocalists.

It is clear that without the availability of the technical tools and computer programs itself as well as the technical conditions for their use in individual classes, the process of mastering the students in the process of training technical tools and software will be impossible. In modern social realities, if classical voice classes are still possible without many technical tools and equipment (although it is not desirable), modern classes of pop singing without them become virtually impossible, and the training of a modern pop singer - vocalist ceases to be comprehensive if he will not be able to fully use the technical tools. The training of specialists in the specialty «Pop singing» must be carried out in the context of the appropriate class of pop singing with the corresponding musical - technical complex or educational recording studio. For the individual classes in the class of pop vocal a musicaltechnical complex is required which must include: a) personal monitor systems of musicians (vocal monitors, guitar, bass and keyboard combo-amplifiers), necessarily with the presence of linear output and the possibility plug in headphone jack and speaker off; b) broadband audio amplifier set with a mixing console with the appropriate number of channels with commutation; c) adaptive racks: microphone (by number according to the number of students and microphones), racks for combo amplifiers and acoustic systems, racks for musical instruments; d) microphone and instrument cables; e) multichannel mixer console and so on. However, since the acquisition of musical-technical is not the subject of this article exhaustively describe this aspect, as well as a complete list of equipment, do not consider appropriate.

B. High level of proficiency in the specialty by the method of using technical tools and computer programs for individual classes on pop singing.

It is obvious that in order to teach students how to use specific technical tools and software, the teacher should be well aware of the capabilities of these tools and software, have a method of their use and have a thorough knowledge of the methods of teaching students the use of technical tools and software. However, in addition to this, the conditions of the modern educational environment place additional conditions on the personality of the pop music teacher, among which, in addition to the deep knowledge of the technique of singing and mastering vocal techniques, a thorough psychological and pedagogical training, a broad outlook, knowledge of the history of contemporary music and pop music vocal performances, interpretations of modern pop vocal works, vocal improvisation, as well as sound processing. The teacher of pop singing at the institution of higher education must be capable of constant self-improvement, as pop music art as well as the technical component of pop performance is developing dynamically, therefore, for an important condition, for constant learning from modern youth there is a constant development in the professional sense. We believe that the modern teacher of pop singing should act as a specialist in the specialty, who thoroughly possesses the teaching methods of vocal techniques and the use of technical tools, as well as a sound engineer, a consultant on the history and theory of contemporary pop music, and the interpretation of modern pop music. 
C. Sufficient level of readiness of future artists - vocalists for mastering the methodology of using technical means and computer software in the process of studying the disciplines of the cycle of vocational training.

Since most of the entrants who enter specialization «Pop singing» do not have basic musical education, as well as informational and technical education, the process of professional training for them is substantially complicated, especially during the first semesters. At the same time, the mastery of technical tools and software first requires considerable time and effort, which modern students are not always ready to do. Obviously, such unpreparedness is connected, first of all, with incomplete notions about the possibilities of technical tools, the external difficulty in mastering them for beginners, as well as lack of awareness of the role of technical tools in the process of fulfilling their professional duties by contemporary vocalists. Accordingly, the task of the teacher of pop singing is to familiarize students - beginers in the first individual lessons with the value and capabilities of technical tools and computer programs in order to increase the interest of students in this component of the process of training. In addition, as a rule, first-year students are not able to practice the competences they acquire in the process of professional training, they can not implement them outside the university, since the vast majority of students work not on a specialty. The following condition for the use of technical tools and software in the process of training future bachelors of musical art - artists-vocalists is directly related to this.

D. High level of mutual integration of the training courses of the cycle of professional training, the subject of which is mastering the students method of using technical tools and computer programs and enhancing the content of practical training in the programs of these courses.

It is advisable that curricula and educational-professional programs provide for the enhancement of the continuity and integrity of training courses in the professional training cycle. So during the first four semesters, along with the course «Pop Singing» students study courses «Musical Acoustics and Sound processing» and «Fundamentals of Sound Recording», which in the complex allows to master the use of basic technical tools and software in the course of the first year, which is in the process of further professional training is deepened and improved. Along with this, it is envisaged to expand the practical component of the training process both in the content of the mentioned educational disciplines, both during and during the organization of individual forms, which allow to realize the practical component of professional training. These events include thematic concerts, charity concerts, open academy concerts, participation of students in contests of vocalists of the different levels, and so on.

It is obvious that it is impossible to exhaust within one article the method of using all the technical tools that it is expedient to use on individual lessons with the future pop singers vocalists, therefore, the focus will be on the main technical tools and computer program. The method of using technical tools on individual lessons from the course «Pop singing» impresses with the expedient to consider in the order of passing through them an audible signal. It is quite obvious that these tools are used in an inseparable unity and do not function separately, but with a theoretical and methodological purpose, we will conditionally separate them. Accordingly, the first technical tool that perceives the sound vibrations formed by the phonation apparatus of the singer is a microphone. It is well-known that there are two main types of microphones acting on the principle:

a) dynamic microphones - they have the sound waves forced to oscillate a membrane with a coil, which is placed in a constant magnetic field; the coil crosses the lines of force of the magnetic field, and in its windings there are induction currents;

b) condenser microphones in which they convert the sound vibrations into electric ones in such microphones corresponds to a capacitor whose one plate is still immobile and the 
other acts as a membrane, that is, it can start to move under the action of sound waves, and since the capacitor is connected to a DC source, capacitor capacitance changes and the AC current becomes variable.

However, for the method of using the microphone more important is the division of microphones in types of direction: a) non-directional; b) bidirectional; c) cardioid direction; d) supercardioid direction; e) hyperkardioid direction. Knowledge of the direction of the microphone, which the pop performer sings, allows him to use, for example, in order to avoid the sound of a heavy breath in the mix if there is no gates in the audio path or if it is incorrectly configured. The method used for this purpose is: for microphones of hypercardioid direction, which have a relatively small angle to the front, in which the sound is perceived, if the singer holds it in his hands, it is enough before the breath to reject the microphone from the face side to 20-30 degrees with the possible small (up to 10 degrees ) turning the head in the opposite direction. This will allow not to remove the microphone far from the face and keep the distance between the membrane and the organs of the phonation of the performer to inhale before the beginning of the musical phrase so that this breath was not perceived by the microphone. With the use of such a technique, contact with the audience is maintained, and this action is not very noticeable for most viewers. Half-professional siger-performers often to achieve the same effect, or turn their heads aside or lower the microphone to the level of the upper abdomen. Both of these variants are not permissible for a professional performer, since in the first case the visual contact with the viewers is unreasonably lost, while in the second, the distance between the organs of the phonation and the membrane of microphone is lost, respectively, the next performed musical phrase will have a different dynamic color, it will either be considerably quieter, or, on the contrary, louder.

Also, for the method of using microphones, the conditional classification according to the transmission mechanism is important: a) the cable - the signal from the microphone is transmitted using a cable; b) radio - microphones - the signal is transmitted by radio signal from the transmitter integrated into the microphone to the receiver. Both variants of signal transmission from the technical point have both advantages and disadvantages, but from the methodological point of view, assuming that the probability of loss of signal from the microphone in the event of an emergency is approximately the same for both methods of signal transmission, the lack of only a cable microphone, because it is conditional restricts the ability of the artist's stage motion to the length of the cable. In order to reduce the probability of tensioning the microphone cable during the motion of the scene, which may either lead to it being cut off from the connector, or damage (break of one of the conductors) and, consequently, to loss of the signal from the microphone, it is advisable to break loop from the microphone cable near the place of its connection with a microphone approximately $50 \mathrm{~cm}$ long, which hold with hand along with the microphone. This will allow, in the case of tensioning the microphone cable due to the movement of the scene, first of all, to stop the movement in this direction, as well as to weaken it by reducing the size of the loop. In addition, this method will prevent the failure of the microphone cable in the most vulnerable to damage in the place - at the plug, because the load is distributed throughout the loop.

If we do not stop separately in the method of working with the preamplifier before the main device is a mixing console. It is clear that the use of a mixing console remote has a sound engineer, but in terms of rehearsal work on individual classes, students also have to master the general settings of the mixing console. In the settings of the microphone channel, any mixing console contains an equalization section. For vocal microphones, most of the remote controls have a switch that activates the frequency filter - cutting off the low frequencies of the audio signal (usually below $80 \mathrm{Hertz}$ ). This filter should be activated because the human voice does not have the basic frequencies in such a low range, therefore, in the absence of such a filter, the microphone in this frequency band will only accept low 
frequency interruptions and other low frequency signals that are not characteristic of the human voice, therefore, their penetration into the microphone channel is undesirable. Similarly, it is methodologically advisable to filter a high frequency band (usually above 15 KiloHertz), since this frequency range is not the same as the human voice, especially since these frequencies contain «frequency rests» of the sizzling sounds of the language, the reproduction of which is also undesirable.

In addition, a separate important aspect is the use of a mixing console for educational audio recordings. Performing sound recordings of singing in individual classes has an indisputable value and is aimed at the implementation of many tasks of professional training: a clear fixation of mistakes in performance (inaccuracies of intonation, phrasing, dynamic shades, tempo rhythms of vocal work, etc.); comparing performances of famous pop performers with their own (especially not for the purpose of «copying» the performance, but for studying the peculiarities of the use of vocal techniques, the specifics of style and manner of execution, etc.); self-critical evaluation by a student of his own recording performance from the listener's point of view (for training finding mistakes in their own vocal performance and eliminating them); tracking progress in learning a particular vocal piece (the possibility of comparing the recording of the performance of the work at the beginning of work with him and at the stage of readiness of the work to stage performance).

It is particularly expedient in the beginning of mastering pop singing is the recording of all individual lessons, since it allows, along with the recording of their own performances, to record an explanation of the teacher, showing the teacher correct intonation, the implementation of complex vocal fragments, etc. Accordingly, in the process of independent work, students are able to listen to the sound recordings of classes and more accurately work on improving their singing. In the first stage for educational recording, in addition to the mixing console, you need a personal computer with an audio interface (if the audio interface is not built into the mixing console) with the software installed on it - the digital audio workstation (DAW). In our opinion, the Adobe Audition digital audio workstation is optimally suited for educational recording, since it requires a minimum number of settings. The audio recording method using the «analog» mixing console without the built-in audio interface and the Adobe Audition CC (Adobe Audition CC, 2017) requires cables for switching the outputs of the mixing console with the audio interface inputs. The main possible connection options are: a) connecting the control outputs of mixing console to the inputs of the audio interface (in which case the audio will be recorded in the stereo mode, taking into account the settings of the master section of the mixing console and the effects of mixing console); and b) connecting the aux outputs of mixing console with audio inputs interface (in which case the sound recording will be performed in dual mono mode). If the audio interface has a sufficient number of inputs, the sound recording can be performed without the use of the mixing console, and with the possibility of recording the vocals in a separate mono track, and the accompaniment - in a separate stereo track. Such a sound recording can be made and subsequently used as a training material in the course «Fundamentals of sound recording».

It is obvious that other computer programs are used on individual singing lessons, but it is impossible to exhaust in one article the method of using all computer programs that are used in classes.

In order to use the software in the process of mastering the future pop singers of the course «Pop singing», certain conditions must be observed.

A. Availability of technical conditions for providing individual classes with students of specialization «Pop singing» (accordingly, an educational studio is equipped with a complete musical and technical complex, which includes, at least, a microphone, a mixing console, an audio interface, a personal computer, a headset and a switching components for connecting component components of the musical-technical complex). 
B. Availability of the appropriate level of professional training and qualification of the pop music teacher who is capable of working at a high theoretical and practical level in a training studio at individual classes with students of specialization «Pop singing» in the process of mastering professional competence.

C. Willingness and motivation of students of specialization «Pop singing» to work on individual lessons of the course «Pop singing» in the conditions of a study studio to fulfill all program requirements of the course.

On the basis of the foregoing, it may be noted that the use of technical tools and software in the process of training future bachelors of music art is irrevocably important, therefore the further expansion of the use of such tools will greatly affect the readiness to perform their professional duties by future artists - vocalists in the process of training for specialty.

Conclusions. In a modern post-informational society, when technologies are widespread, mastering of technical tools and software is an indispensable part of the process of professional training, in particular, in artistic specialties. Competent use of a artist-vocalist of technical tools in the course of performance can significantly increase the artistic level of the technical-performing level of the vocal work that is performed. He is trained in the use of modern technical tools and computer programs that a future actor-vocalist can meet at his workplace in the course of his professional training in the specialty «Musical art» at the institution of higher education. Based on the analysis of the realities of the Ukrainian labor market and requests for the professional competence of specialists specializing in «Music Art», it is necessary to take into account the development of modern technologies, tools and equipment, and their study and widespread use in the process of professional training of the future artist-vocalist.

The analysis of scientific theoretical and methodological works and the synthesis of practical experience in the training of singers - vocalists allowed to specify the conditions of use of technical tools and software in the process of professional training of future bachelors of musical art, to isolate the components of methods of using specific technical tools and computer programs to ensure the mastery of students by specialty individual lessons of the course «Pop singing».

The use of modern technical tools and software is an urgent requirement for a modern process of professional training of specialists in higher education institutions of culture and art, therefore the development of methodological principles for the use of technical tools and computer programs remains relevant. The most promising directions are the development of the latest programs of training of high educational institutions teachers of arts specialties, capable of using modern achievements of electronic technologies, development of methodical principles for the use of specific technical tools used in modern artistic educational institutions of higher education, deepening of interdisciplinary connections of courses of the cycle of professional training and mutual integration these courses for the formation and development of professional competence.

\section{REFERENCES}

1. Austin S. (2008). Building Strong Voices: Twelve Different Ways! (Part II) Choral Journal. 48.8 (February 2008). 59-73.

2. Lebon R. (1999). The Professional Vocalist: A Handbook for Commercial Singers and Teachers. Lanham, Md. and London: The Scarecrow Press. 160.

3. LoVetri J. (2003). Voice Pedagogy: Female Chest Voice. Journal of Singing. 60.2 (November/December 2003). 162.

4. Edwin R. (1996). Attitude as Vocal Technique. Journal of Singing 53.2 (November 1996). 51-53.

5. Miller R. (2000). Training Soprano Voices London: Oxford University Press. 36. 
6. Peckham A. (2006). Vocal Workouts for the Contemporary Singer Boston: Berklee Press. 118

7. Riggs S. and Carrtello J. (1998). Singing for the Stars: A Complete Program for Training Your Voice. Rev. Ed. Van Nuys, CA: Alfred. 96.

8. Bozeman K. (2007). A Case of Voice Science in the Voice Studio. Journal of Singing 63. 3 (January 2007). 265-270

9. Heinze C. (1997). Avoiding Vocal Damage. Canadian Musician. 19.4 (August 1997). 31.

10. Adobe Audition CC. (2017). A professional audio workstation. October 12, 2017. https://www.adobe.com/products/audition.html

Text of the article was accepted by Editorial Team 04.11.2018

УДК 370.036-373.67

Фоломссва Наталія

Кандидат педагогічних наук, кафедра хорового диригування, вокалу та методики музичного навчання, доцент

Сумський державний педагогічний університет імені А.С. Макаренка, Суми, Україна

folomeeeva.natalya.arkadievna@gmail.com

ORCID ID 0000-0002-7832-4748

\title{
МЕТОДИКА ВИКОРИСТАННЯ ТЕХНІЧНИХ ЗАСОБІВ ТА ПРОГРАМНОГО ЗАБЕЗПЕЧЕННЯ ПРОЦЕСІ ФАХОВОЇ ПІДГОТОВКИ МАЙБУТНІХ АРТИСТІВ - ВОКАЛІСТІВ
}

\begin{abstract}
Анотація. Стаття присвячена основам методики використання технічних засобів та програмного забезпечення у процесі професійної підготовки майбутніх бакалаврів музичного мистецтва - артистів-вокалістів у мистецьких закладах вищої освіти. Пропонуються основні умови використання технічних засобів та програмного забезпечення в процесі професійної підготовки майбутніх бакалаврів музичного мистецтва - артистіввокалістів у закладах вищої освіти. Також у статті визначаються умови використання програмного забезпечення у процесі засвоєння майбутніми артистами-вокалістами курсу «Естрадний спів» у процесі професійної підготовки за спеціальністю «Музичне мистецтво». У дослідженні викладено основні методичні рекомендації з використання особливостей направленості мікрофона та еквалайзера мікшерського пульта на індивідуальних заняттях 3 естрадного співу у процесі професійної підготовки майбутніх естрадних вокалістів. Робиться акцент на значенні використання в процесі професійної підготовки майбутніх бакалаврів музичного мистецтва програмного забезпечення для звукозапису репетиційної роботи. Робиться висновок про необхідність і значення подальшого удосконалення навчальних планів та освітньо-професійних програм спеціальності «Музичне мистецтво» 3 метою поглиблення практичної та технічної складової процесу професійної підготовки, зокрема, за спеціалізацією «Естрадний спів».
\end{abstract}

Ключові слова: естрадний спів; музичне мистецтво; бакалавр музичного мистецтва; технічні засоби; програмне забезпечення; Adobe Audition; мікрофон; мікшерський пульт. 